Original Research

\title{
Physicochemical Properties of Wastewater in Three Typical South African Sewage Works
}

\author{
Mojeed A. Agoro ${ }^{1,2 *}$, Omobola O. Okoh ${ }^{1,2}$, Martins A. Adefisoye ${ }^{1,3}$, \\ Anthony I. Okoh ${ }^{1,3}$ \\ ${ }^{1}$ SAMRC Microbial Water Quality Monitoring Centre, University of Fort Hare, Alice, South Africa \\ ${ }^{2}$ Department of Chemistry, University of Fort Hare, Private bag X1314, Alice 5700, South Africa \\ ${ }^{3}$ Applied and Environmental Microbiology Research Group (AEMREG), Department of Biochemistry \\ and Microbiology, University of Fort Hare, \\ Private bag X1314, Alice 5700, South Africa
}

Received: 25 Jauary 2017

Accepted: 28 May 2017

\begin{abstract}
The physicochemical qualities of the effluent samples of three municipal sewage treatment plants in the Eastern Cape of South Africa were evaluated from September 2015 to February 2016 using standard methods. The physicochemical parameters assessed include $\mathrm{pH}$, temperature, total dissolved solid (TDS), turbidity, chemical oxygen demand (COD), alkalinity, dissolved oxygen (DO), free chlorine, chloride, sulphate, phosphate, ammonium, and electrical conductivity (EC). The results of the evaluation were as follows: temperature $\left(19-36^{\circ} \mathrm{C}\right), \mathrm{EC}(60-1,095 \mathrm{mS} / \mathrm{m})$, alkalinity $(2.6-20.9 \mathrm{mg} / \mathrm{L})$, nitrate (0.24-26.5 mg/L), nitrite $(0.01-90 \mathrm{mg} / \mathrm{L})$, phosphate $(0.02-5.12 \mathrm{mg} / \mathrm{L})$, ammonium $(0.06-112 \mathrm{mg} / \mathrm{L})$, sulphate (3-72 mg/L), chloride (3.25-224 mg/L), COD (17-394 mg/L), and turbidity (1.96-715 NTU). Free chlorine concentrations and DO were within the recommended limits for most of the sampling period and ranged between 0.17-0.48 $\mathrm{mg} / \mathrm{L}$ and 0.19-21.9 mg/L, respectively. Also, the $\mathrm{pH}$, phosphate, sulphate, and free chlorine concentrations were within acceptable limits, while EC, temperature, TDS, turbidity, COD, chloride, ammonium, nitrate, and nitrite did not conform to recommended limits. We conclude that these municipal sewage plants are sources of pollution to their respective receiving watersheds and threats to public and environmental health.
\end{abstract}

Keywords: physicochemical, wastewater effluent, sewage treatment, pollution, surface water

*e-mail: amodoyin@gmail.com 


\section{Introduction}

Municipal wastewater treatment plants often discharge their treated effluents back to the environment, most especially surface water environments. Untreated or inadequately treated municipal sewage discharges may contain public health compromising pathogens and hazardous elements (e.g., heavy metals) as well as chemical substances that could lead to hostile environmental effects such as alterations of aquatic organism behaviours and structure, reduction in diversity of life on earth, diminishing the quality of recreational waters and shellfish harvesting zones, and polluting of water meant for consumption [1-2]. Apart from the adverse effect on the environment, the different levels of chemical and microbiological constituents in discharged wastewater effluent bring additional pressure to bear on the already stressed freshwater resources in many developing countries [3-4].

It has been reported that the use of freshwater polluted by industrial and municipal effluents for irrigation has negative effects on agricultural produce due to changes in the physicochemical properties of the watershed [5]. The toxic chemicals may destroy the aquatic organisms, which in turn may result in the disruption of the food chain and aquatic ecosystem [6]. Good quality surface water relies on various factors including its physicochemical characteristics as well as the magnitude of the pollution load. The physicochemical characteristics of the water can reveal particular conditions for the ecology of aquatic organisms and suggest suitable conservation and management strategies [7-8].

The main purpose of municipal treatment plants is to remove/reduce organic wastes in order to avoid a decrease in dissolved oxygen in the receiving watershed, eliminate pollutants in order to avoid excessive richness of nutrients, and safeguard human health by deactivating microorganisms capable of causing disease [9-10]. Some of the major treatment technologies used in treating wastewater effluents include the activated sludge system, bio-filters, oxidation ponds, and membrane filtration, among others. The selection of the appropriate treatment process is determined by wastewater characteristics, plus environmental and economic considerations [1113]. Indiscriminate discharge of untreated or poorly treated domestic and industrial wastewater effluents are major contributors to surface water pollution with its attendant problems such as increased biochemical oxygen demand (BOD) and nutrient loading, which in turn may have adverse effects on public health and environmental conservation [14-15].

In many developing countries such as South Africa, the past few years have witnessed a drastic increase in the volumes of municipal wastewater discharged into the environment, mainly due to the continuous increase in human population and urbanization. This comes along with the attendant challenges that include environmental pollution, threats to public health, and increased reliance on rapidly diminishing water resources [3]. In this paper, we report on the physicochemical properties of the wastewater effluents of three typical sewage works in some communities in the Eastern Cape Province of South Africa, and their compliance with recommended limits for the protection of human and environmental health.

\section{Materials and Methods}

\section{Study Area Description}

The three sewage treatment works selected for this study are located in the Eastern Cape Province. The plants are identified by the codes WWTP-A (Alice wastewater treatment plant), located within the geographical coordinates $32^{\circ} 47^{\prime} 55^{\prime \prime} \mathrm{S}, 26^{\circ} 50^{\prime} 95^{\prime \prime} \mathrm{E}$; WWTP-B (Berlin wastewater treatment works), located within coordinates $32^{\circ} 50^{\prime} 70^{\prime \prime} \mathrm{S}, 2^{\circ} 37^{\prime} 04^{\prime \prime} \mathrm{E}$; and WWTP-C (Bedford wastewater treatment works), located within the coordinates $32^{\circ} 41^{\prime} 15^{\prime \prime} \mathrm{S}, 26^{\circ} 06^{\prime} 29^{\prime \prime} \mathrm{E}$. WWTP-A uses activated sludge technology, while WWTP-B and WWTP-C use bio-filter and oxidation pond technologies, respectively.

\section{Water Sample Collection}

Water samples were collected from four different points at each study site, including influent, effluent, $500 \mathrm{~m}$ upper stream, and $500 \mathrm{~m}$ downstream from the discharge points. From each sampling point, water samples were collected in polyethene bottles prewashed with nitric acid and rinsed thoroughly with distilled water. The samples were then transported on ice to the Applied and Environmental Microbiology Research Group (AEMREG) Laboratory at the University of Fort Hare, Alice, South Africa for analysis. All samples were kept refrigerated at $4^{\circ} \mathrm{C}$ and processed within 24 hours of collection. Sampling was done monthly for a period of six months from September 2015 to February 2016.

\section{Physicochemical Analyses}

All equipment and meters for the on-site measurements were calibrated and checked according to the manufacturer's instruction. Temperature (T), $\mathrm{pH}$, electrical conductivity (EC), total dissolved solids (TDS), and dissolved oxygen (DO) were measured using a Hanna multi-parameter probe HI 9828, while turbidity (TUR) was measured using a microprocessor turbidimeter (HACH Company, model 2100P). Chemical oxygen demand (COD) samples were digested in a thermo reactor Model TR 300 (Merck Pty Ltd.) and measured using a spectroquant Pharo 100 instrument [16]. The concentration levels of nitrate, nitrite, phosphate, sulphate, chloride, and ammonium (Merck Pty Ltd.) were analyzed using the spectroquant Pharo 100 [17], while Alkalinity of the water samples was determined through titration. The free chlorine was quantified using the DPD method [18]. 


\section{Calculation of Efficiency of Wastewater Treatment [19]}

$$
\text { Removal efficiency } \%=\underset{\mathrm{Ci}}{\mathrm{Ci}-\mathrm{Ce}} \times 100
$$

...where $\mathrm{Ci}$ is concentration of waste matter in influent and $\mathrm{Ce}$ concentration of waste matter in effluent.

\section{Statistical Treatment of Data}

The data obtained were analyzed using descriptive statistical analysis at a 95\% confidence interval. SPSS was used for the one-way analysis of variance (IBM SPSS version 20), mean, and range. t-Test was used to test variations among all possible pairs of treatments. Correlation was performed using the Pearson procedure of SPSS.

\section{Results and Discussion}

The results of the physicochemical qualities of the wastewater samples are presented in Table 1. The temperature profile generally varies significantly $(P<0.05)$ and ranged between 19 and $36^{\circ} \mathrm{C}$ at all sampling points. The lowest and the highest temperatures were both recorded at WWTP-C. The temperature complied with set limits for discharged effluent for most of the sampling period except in January, when $36^{\circ} \mathrm{C}$ was recorded due to the prevailing atmospheric conditions. This may also be due to the prolonged holding of the effluents in oxidation ponds at WWTP-C. High temperature may produce softening of bituminous joints and increase odour as a result of anaerobic reaction, and can be deteropans to the pipe material itself [20], the temperature of the effluents may pose a threat to the aqua-based organisms, which is not in conformity with the report of [21], but was similar to the reports of [20].

The $\mathrm{pH}$ values as observed in this study fell within the guideline limit for discharged effluents into a receiving waterbody, although there were variations at all the treatment plants in January and February, which may be due to increases in temperature during the summer season. The $\mathrm{pH}$ of the water is known to affect the availability of micronutrients as well as trace and heavy metals. The $\mathrm{pH}$ level of water defines its utility for a different purpose. It has been established that $\mathrm{pH}$ is a vital characteristic in assessing the acid-base level of water. Low or high $\mathrm{pH}$ has a toxic effect on aquatic life and alters the solubility of other chemical pollutants as well other important elements in surface water. This may lead to adverse effects on those that depend on it for various uses and also the ecosystem. The South African recommended limit for $\mathrm{pH}$ in water for domestic use is 6 to 9 [22].

The profile of EC observed at all sites varied from 60 to $1,095 \mathrm{mS} / \mathrm{m}$ and differs significantly $(P<0.05)$ with the highest and lowest values obtained at WWTP-A downstream and WWTP-B downstream, respectively.
EC values higher than the recommended limit of $450 \mathrm{mS} / \mathrm{m}$ were observed downstream from the WWTP-B watershed throughout the sampling period. This suggests that there could be other unidentified contaminants gaining access to the watershed. EC is mainly attributed to the dissolved ions from the decomposed plant matter. The EC of the surface water is a valuable indicator of salinity with total salt content. An increase in EC values points to the high amount of dissolved inorganic substances in ionized form. A high level of chlorine concentration also contributed to the increase in EC [23]. The value reported from this study is in line with the report of Singh et al. [20] and Ewemoje and Ihuoma [24]. Also, the highest TDS concentration $(701 \mathrm{mg} / \mathrm{L})$ was obtained in WWTP-B downstream samples, which may suggest that there could be external pollution of the watershed by industrial effluents located in the vicinity of the river. The TDS values at all sampling points generally vary significantly $(P<0.05)$ and were between $60-701 \mathrm{mg} / \mathrm{L}$. A high concentration of TDS could be lethal to aquatic organisms, leading to osmotic shock thereby, affecting the osmoregulatory strength of the organism [25]. The concentrations of TDS in irrigation water hinder plant growth, crop yield, and quality of product [26]. The TDS values obtained in this study are similar to those reported previously by [27].

The DO in WWTP-A treatment plant effluent fell within recommended limits [22] in September, October, December, and February, and were low in November and January, while at WWTP-B, the DO was in agreement with the South African guidelines for effluents and downstream except for December in the final effluent. The DO at WWTP-C was low in January and February in the final effluent, but was within the limit in September $6.52 \mathrm{mg} / \mathrm{L}$ and October $8.06 \mathrm{mg} / \mathrm{L}$, while high DO concentrations were detected in November and December in the effluents. DO is used to determine the level of pollution by organic matter and the demolition of organic substance, as well as the self-purification strength of water bodies. DO is a guide of physical and biological process in water. The acceptable standard for drink purposes is $6 \mathrm{mg} / \mathrm{L}$ and for aquatic organisms is $4-5 \mathrm{mg} / \mathrm{L}$. DO in concentration in unpolluted water normally ranges from $8-10 \mathrm{mg} / \mathrm{L} \mathrm{[18].} \mathrm{Low} \mathrm{DO} \mathrm{in}$ water disturbs the existence of fish by increasing their susceptibility to disease, migration, and reproductive behaviour, hindering swimming capacity, fluctuating feed, and leading to death of aquatic life [28]. Inorganic compounds such as ammonia nitrites, hydrogen sulphates, and Ferro ions also have a tendency to decrease the oxygen in water.

Biochemical oxygen demand is described as the amount of oxygen required to break down organic substances in water while COD is the amount of strong oxidant required to break down both organic and inorganic matters [29]. The BOD profiles throughout the sampling period generally ranged from $3.7-14 \mathrm{mg} / \mathrm{L}$, while the COD ranged from $17-394 \mathrm{mg} / \mathrm{L}$. BOD in the aquatic system is caused by high levels of organic matters such as leaves 
Table 1. Ranges of physicochemical analysis obtained at the three study sites with their percentage reductions.

\begin{tabular}{|c|c|c|c|c|c|c|c|c|c|c|}
\hline \multirow{2}{*}{ Parameters } & \multirow{2}{*}{$\begin{array}{l}\text { Sampling } \\
\text { point }\end{array}$} & \multicolumn{3}{|c|}{ WWTP-A } & \multicolumn{3}{|c|}{ WWTP-C } & \multicolumn{3}{|c|}{ WWTP-B } \\
\hline & & Range & t. Test & $\mathrm{P}<0.05$ & Range & t. Test & $\mathrm{P}<0.05$ & Range & t. Test & $\mathrm{P}<0.05$ \\
\hline \multirow{4}{*}{$\mathrm{DO} \mathrm{mg} / \mathrm{L}$} & Influent & $0.25-1.53$ & 2.952 & .032 & $0.2-1.45$ & 3.766 & .013 & $0.19-4.58$ & 3.407 & .019 \\
\hline & Effluent & $1.37-8.33$ & 5.852 & .002 & $0.8-21.9$ & 2.720 & 042 & $2.75-10.7$ & 6.616 & .001 \\
\hline & U. Stream & $5.02-8.14$ & 15.075 & .000 & & & & & & \\
\hline & D. Stream & $4.82-7.75$ & 9.897 & .000 & & & & $6.34-8.84$ & 17.687 & .000 \\
\hline \multirow{4}{*}{$\mathrm{pH}$} & Influent & $7.04-8.77$ & 23.426 & .000 & $7.02-8.65$ & 23.617 & .000 & $7.01-8.77$ & 26.699 & .000 \\
\hline & Effluent & $7.03-8.77$ & 31.998 & .000 & $7.03-8.95$ & 22.947 & .000 & $7.04-8.67$ & 23.529 & .000 \\
\hline & U. Stream & $7.03-8.85$ & 20.987 & .000 & & & & & & \\
\hline & D. Stream & $7.03-8.98$ & 22.788 & .000 & & & & $7.05-8.88$ & 26.042 & .000 \\
\hline \multirow{4}{*}{$\mathrm{EC} \mathrm{mS/m}$} & Influent & $255-319$ & 32.017 & .000 & 276-306 & 61.966 & .000 & $393-712$ & 12.546 & .000 \\
\hline & Effluent & $211-259$ & 19.417 & .000 & $268-368$ & 19.982 & .000 & $373-568$ & 12.858 & .000 \\
\hline & U. Stream & $104-152$ & 9.401 & .000 & & & & & & \\
\hline & D. Stream & $93-255$ & 6.473 & .000 & & & & 190-1095 & 4.534 & .006 \\
\hline \multirow{4}{*}{ TDS mg/L } & Influent & $163-204$ & 32.383 & .001 & 176-196 & 61.212 & .000 & $252-401$ & 13.335 & .000 \\
\hline & Effluent & $63-165$ & 19.432 & .000 & $171-235$ & 20.043 & .000 & $238-364$ & 12.839 & .000 \\
\hline & U. Stream & $66-125$ & 9.405 & .000 & & & & & & \\
\hline & D. Stream & $60-163$ & 6.197 & .000 & & & & $162-701$ & 4.845 & .005 \\
\hline \multirow{4}{*}{$\mathrm{T}^{\circ} \mathrm{C}$} & Influent & $22-30.1$ & 19.221 & .002 & $18.8-36.3$ & 10.241 & .000 & $20.5-32.8$ & 13.268 & .000 \\
\hline & Effluent & $22.5-29.8$ & 25.099 & .000 & $20.6-35.1$ & 12.449 & .000 & $20.9-31.4$ & 16.941 & .000 \\
\hline & U. Stream & $22-29$ & 24.238 & .000 & & & & & & \\
\hline & D. Stream & $22.3-29.3$ & 22.774 & .000 & & & & $20-31.6$ & 14.306 & .000 \\
\hline \multirow{4}{*}{ ALK mg/L } & Influent & $5.2-11$ & 5.722 & .002 & $2.87-7.7$ & 5.635 & 002 & $8-15$ & 11.662 & .000 \\
\hline & Effluent & $4.1-9.2$ & 9.720 & .000 & $6.1-16.1$ & 7.196 & .001 & $2.6-20.9$ & 3.356 & .020 \\
\hline & U. Stream & $3.4-15.5$ & 4.632 & .006 & & & & & & \\
\hline & D. Stream & $3.5-9.9$ & 6.491 & .001 & & & & $3.2-9.2$ & 6.573 & .001 \\
\hline \multirow{4}{*}{$\mathrm{NO}_{3} \mathrm{mg} / \mathrm{L}$} & Influent & $2.3-26.5$ & 3.258 & .022 & $1.6-22$ & 2.951 & .032 & $0.24-25$ & 2.580 & .049 \\
\hline & Effluent & $4.2-9.7$ & 7.616 & .001 & $4.6-20.8$ & 3.562 & .016 & $0-4.7$ & 4.603 & .006 \\
\hline & U. Stream & $3.9-10.4$ & 6.698 & .001 & & & & & & \\
\hline & D. Stream & 2.4- 6.3 & 7.253 & .001 & & & & $0.7-8.6$ & 2.920 & .033 \\
\hline \multirow{4}{*}{$\mathrm{NO}_{2} \mathrm{mg} / \mathrm{L}$} & Influent & $0.93-48.5$ & 2.626 & .047 & $17-54.1$ & 5.199 & .003 & $0.14-90$ & 1.204 & .283 \\
\hline & Effluent & $0-17.9$ & 1.407 & .218 & $0.75-32.4$ & 2.279 & .072 & $0.02-10.4$ & 1.181 & .291 \\
\hline & U. Stream & $0.04-48.6$ & 1.169 & .295 & & & & & & \\
\hline & D. Stream & $0.04-32.6$ & 1.800 & .132 & & & & $0.01-11.7$ & 1.160 & .298 \\
\hline \multirow{4}{*}{$\mathrm{PO}_{4} \mathrm{mg} / \mathrm{L}$} & Influent & $0.06-3.71$ & 4.076 & .010 & $0.42-3.56$ & 3.842 & .012 & $0.96-5.12$ & 4.155 & .009 \\
\hline & Effluent & $0.64-3.63$ & 5.918 & .002 & $0.05-5$ & 3.374 & .020 & $0.04-2.0$ & 4.306 & .008 \\
\hline & U. Stream & $0.06-2.35$ & 2.383 & .063 & & & & & & \\
\hline & D. Stream & $0.1-2.92$ & 2.631 & .046 & & & & $0.02-1.03$ & 2.579 & .049 \\
\hline
\end{tabular}


Table 1. Continued.

\begin{tabular}{|c|c|c|c|c|c|c|c|c|c|c|}
\hline \multirow{4}{*}{$\mathrm{NH}_{4}{ }^{2-} \mathrm{mg} / \mathrm{L}$} & Influent & $8-112.5$ & 1.912 & .114 & $0.73-37.3$ & 3.632 & .015 & $0.16-98$ & 1.227 & .274 \\
\hline & Effluent & $6.4-130$ & 1.709 & .148 & $0.57-46$ & 2.843 & .036 & $0.06-3.87$ & 2.957 & .032 \\
\hline & U. Stream & $2.3-56.0$ & 2.036 & .097 & & & & & & \\
\hline & D. Stream & $1.7-55.3$ & 1.655 & .159 & & & & $0.06-4.5$ & 2.986 & .031 \\
\hline \multirow{4}{*}{$\mathrm{SO}_{4} \mathrm{mg} / \mathrm{L}$} & Influent & $40-72$ & 8.082 & .000 & $26.5-55$ & 10.525 & .000 & $37-71$ & 9.192 & .000 \\
\hline & Effluent & $13-31$ & 8.681 & .000 & $3-41$ & 3.145 & .026 & $14-43$ & 6.181 & .002 \\
\hline & U. Stream & $8-28$ & 4.537 & .006 & & & & & & \\
\hline & D. Stream & $8.8-30.5$ & 3.707 & .014 & & & & $13.4-30.7$ & 9.752 & .000 \\
\hline \multirow{4}{*}{$\mathrm{CL} \mathrm{mg} / \mathrm{L}$} & Influent & $21-107$ & 3.471 & .018 & $19.9-113.4$ & 4.181 & .009 & 6-139 & 2.711 & .042 \\
\hline & Effluent & $17-87$ & 3.518 & .017 & $21.8-92.4$ & 4.343 & .007 & $23.4-224$ & 2.857 & .036 \\
\hline & U. Stream & $22-74$ & 4.053 & .010 & & & & & & \\
\hline & D. Stream & $16-82$ & 3.425 & .019 & & & & $3.25-200$ & 2.515 & .053 \\
\hline \multirow{4}{*}{$\mathrm{RC} \mathrm{mg} / \mathrm{L}$} & Influent & & & & & & & & & .035 \\
\hline & Effluent & $0-0.22$ & 3.050 & .028 & $0-0.17$ & 1.000 & .363 & $0-0.48$ & 2.879 & .032 \\
\hline & U. Stream & & 1.470 & .202 & & & & & & \\
\hline & D. Stream & & 1.145 & .304 & & & & & & \\
\hline \multirow{4}{*}{ COD mg/L } & Influent & 274-329 & 35.939 & .000 & $114-394.4$ & 4.723 & .005 & $120-315$ & 6.387 & .001 \\
\hline & Effluent & $42-246$ & 2.771 & .039 & $18.7-131.4$ & 3.384 & .047 & $30.7-322$ & 3.317 & .021 \\
\hline & U. Stream & $19-186$ & 2.397 & .062 & & & & & & \\
\hline & D. Stream & $17-199$ & 2.105 & .089 & & & & $28-319$ & 3.309 & .021 \\
\hline \multirow{4}{*}{ BOD mg/L } & Influent & $0-1.2$ & 1.894 & .117 & $0.04-1.19$ & 2.627 & .047 & $0-3.80$ & 3.044 & .029 \\
\hline & Effluent & $0-6.25$ & 1.834 & .126 & $0-14$ & 2.038 & .097 & $2.11-8.12$ & 5.270 & .003 \\
\hline & U. Stream & $0-3.7$ & 1.395 & .222 & & & & & & \\
\hline & D. Stream & $0-6.35$ & 1.225 & .275 & & & & $2.84-7.06$ & 6.739 & .001 \\
\hline \multirow{4}{*}{ TUR NTU } & Influent & $112-580$ & 6.025 & .002 & $297.5-638$ & 9.629 & .000 & $50.3-715$ & 3.013 & .030 \\
\hline & Effluent & $1.96-69.5$ & 2.892 & .034 & $14.7-187$ & 3.969 & .011 & $17.9-209$ & 2.402 & .061 \\
\hline & U. Stream & 19-154 & 4.559 & .006 & & & & & & \\
\hline & D. Stream & $18-145$ & 4.272 & .008 & & & & $18.6-241$ & 3.072 & .028 \\
\hline
\end{tabular}

Key: NA = Not Applicable; $\mathrm{T}=$ temperature; Tur $=$ turbidity; $\mathrm{ALK}=$ Alkalinity; $-=0 \%, *=$ effluents higher than influents, $\mathrm{t}-\mathrm{Test}$, Significant at $\mathrm{P}>0.05$, range of the mean value, $\%$ red $=$ percentage reduction,

and dead plants, animals, industrial effluents, wastewater treatment plants, food processing plants, woody debris, animal manure, and urban storm water runoff. High levels of BOD can be traced to heavy discharge of industrial effluents, domestic sewage, crops, and animal waste [40]. Effluents at WWTP-B and WWTP-C did not comply with the set limits $75 \mathrm{mg} / \mathrm{L}$ for COD in most of the sampling months. This may be attributed to the locations of some industries close to the treatment facilities. High levels of COD in water may point to poor water standards caused by municipal or farmed effluent discharges [30], which may in turn result in higher oxygen depletion that affects aquatic organisms [31]. The observation from this study agrees with Salem et al. [32] for COD and BOD at the receiving watershed.

Generally, the nitrate values obtained ranged $0.24-26.5 \mathrm{mg} / \mathrm{L}$ at the three sampling sites. The values obtained for effluents in WWTP-A and WWTP-B fell within the recommended guidelines of $15 \mathrm{mg} / \mathrm{L}$ [24, 33] over the sampling period, while values that exceeded the limit were recorded at WWTP-C. Nitrate has been identified as capable of inducing eutrophication even at low concentrations $(<1 \mathrm{mg} / \mathrm{L})$ [34-35], which affect aquatic organisms, decrease biodiversity, and cause unpleasant smells, thus rendering the water unfit for recreational uses [36-38]. The nitrite profile level ranged between $0.01-90 \mathrm{mg} / \mathrm{L}$ and differs significantly $(P<0.05)$ at the three treatment plants. High nitrite concentrations 
Table 2. DWAF Regulatory Guidelines 2010 [23].

\begin{tabular}{|c|c|c|}
\hline Parameter units & General limit & Special limit \\
\hline $\mathrm{DO} \mathrm{mg} / \mathrm{L}$ & 75 & 75 \\
\hline $\mathrm{pH}$ & $5.5-9.5$ & $5.5-7.5$ \\
\hline $\mathrm{EC} \mathrm{mS} / \mathrm{m}$ & 75 & 15 \\
\hline $\mathrm{TDS} \mathrm{mg} / \mathrm{L}$ & 450 & - \\
\hline $\mathrm{T}^{\circ} \mathrm{C}$ & 35 & 25 \\
\hline $\mathrm{SO}_{4} \mathrm{mg} / \mathrm{L}$ & 200 & - \\
\hline $\mathrm{PO}_{4} \mathrm{mg} / \mathrm{L}$ & 10 & 1 \\
\hline $\mathrm{NO}_{3} \mathrm{mg} / \mathrm{L}$ & 15 & 1.5 \\
\hline $\mathrm{NO}_{2} \mathrm{mg} / \mathrm{L}$ & 15 & 1.5 \\
\hline $\mathrm{RC}^{\mathrm{mg}} / \mathrm{L}$ & 0.25 & - \\
\hline $\mathrm{CL} \mathrm{mg} / \mathrm{L}^{\mathrm{COD}} \mathrm{mg} / \mathrm{L}$ & 100 & - \\
\hline $\mathrm{BOD}_{\mathrm{mg}} / \mathrm{L}$ & 75 & 30 \\
\hline $\mathrm{NH}_{4}{ }^{2-} \mathrm{mg} / \mathrm{L}$ & $3-6$ & - \\
\hline & 3.0 & 1.0 \\
\hline
\end{tabular}

of $0.2-17 \mathrm{mg} / \mathrm{L}$ and $0.78-32.4 \mathrm{mg} / \mathrm{L}$ were recorded at WWTP-A and WWTP-C treatment plants, respectively, and this may pose a serious danger to the reliability of aquatic organisms. A high concentration of nitrite has also been found to give rise to methaemoglobinenia [39-40]. Phosphate levels observed within the sampling months of the research ranged $0.02-5.12 \mathrm{mg} / \mathrm{L}$ at the three wastewater plants and were within the recommended guidelines of $10 \mathrm{mg} / \mathrm{L}$ in all the points of collection. Phosphate generally is a limiting factor in aquatic environments and leads to various undesirable ecological challenges in the water system [41-42]. High levels of phosphate and nitrates enhance the growth of vegetation in water bodies and increase oxygen demand [18].

The turbidity values obtained at the three treatment facilities were within $1.96-715 \mathrm{mg} / \mathrm{L}$. Although there are no set limits for turbidity in discharged effluent in South Africa, most of the samples grossly exceeded the set standard of 0 to $1 \mathrm{NTU}$ for drinking water as stipulated by DWAF. This disqualifies both the receiving water and the discharged effluent for domestic use [43]. Studies have shown that too much turbidity in water can lead to interference with some treatment steps at some stages, such as coagulation and separation solids of the water treatment techniques, which may increase treatment cost, and when extremely turbid water is chlorinated, there is a possibility for a rise in trihalomethane (THM) precursor formation [18].

The sulphate concentrations at the three plants complied with the DWAF guideline of $200 \mathrm{mg} / \mathrm{L}$ and ranged between 3 and $72 \mathrm{mg} / \mathrm{L}$ throughout the study period. However, values higher than the limits were observed in final effluents from the WWTP-C treatment plant in October and November. Small levels of sulphate in human beings cause a temporary laxative effect. And ingestion of water containing a high level of sulphate may be linked with diarrhoea and other gastrointestinal disorders. [44] suggests that a high value of sulphate is due to detergents and soaps by residents. Also, chloride concentrations ranged from 3.25 to $224 \mathrm{mg} / \mathrm{L}$ over the study period. The higher level obtained in the effluents was due to the poor efficacy of the treatment plant with regards to chloride, and could be due to the industries located in the areas. WWTP-A and WWTP-C fell within the DWAF limit of $100 \mathrm{mg} / \mathrm{L}$ for domestic use in all months. Chloride concentration is affected by treatment due to Sodium chloride, a common component of humans and diet, which passes unchanged through the digestive system in wastewater. At concentrations above $250 \mathrm{mg} / \mathrm{L}$, water will begin to taste salty and will become objectionable as the level rises more and may render freshwater unsuitable for agricultural irrigation [29].

The free chlorine concentration in the effluent followed a pattern similar to that of chloride at WWTP-A and WWTP-B treatment plants, which fell within the [33] guidelines of $0.17 \mathrm{mg} / \mathrm{L}$ to $0.25 \mathrm{mg} / \mathrm{L}$.

Ammonium concentrations vary $0.06-112 \mathrm{mg} / \mathrm{L}$ and differ significantly $(P<0.05)$ at the three treatment facilities. Discharged effluents at WWTP-A and WWTP-C treatment plants did not comply with the set limits and could cause pollution in the receiving watersheds in terms of ammonium. WWTP-B wastewater plant samples were within the DWAF recommended limit of $3.0 \mathrm{mg} / \mathrm{L}$ during the sampling months. High levels of ammonium in water could be either due to sewage or industrial waste and fertilizer runoff [45].

The alkalinity profile ranged $2.6-20.9 \mathrm{mg} / \mathrm{L}$ at the three study sites. Low alkalinity levels were observed downstream from the WWTP-A treatment plant compared to the upstream, while alkalinity was generally high in the WWTP-B-treated effluents, which may be linked to the industrial effluents discharged at the plant. WWTP-C effluents were also higher in alkalinity than the influents, which may be due to long periods of holding the effluents in oxidation ponds, causing an increase in the alkaline nature of the effluents as a result of anaerobic decomposition.

There was no significant correlation between EC and TDS and other parameters $(P<0.05)$ at the WWTP-A treatment plants. There was a significant positive correlation between DO, ALK, $\mathrm{PO}_{4}, \mathrm{CL}, \mathrm{RC}, \mathrm{BOD}$, and TUR ( $\mathrm{r}=.081, .051, .432, .737, .261, \mathrm{P}<0.05)$, respectively, while $\mathrm{pH}, \mathrm{EC}, \mathrm{TDS}, \mathrm{T}, \mathrm{NO}_{3}, \mathrm{NO}_{2}, \mathrm{NH}_{4}, \mathrm{SO}_{4}$, and $\mathrm{COD}$ $(\mathrm{r}=-.260,-.656,-.656,-.764,-.670,-.095,-.419,-.514,-$ $.332, \mathrm{P}<0.05)$ exhibited a significant negative correlation. WWTP-C data showed that there was a significant $(\mathrm{P}<$ $0.05)$ positive correlation between $\mathrm{DO}, \mathrm{PO}_{4}, \mathrm{NH}_{4}, \mathrm{TUR}$, $\mathrm{SO}_{4}, \mathrm{RC}, \mathrm{COD}$, and BOD $(\mathrm{r}=.583, .370, .509, .225, .765$, $.176, .900, \mathrm{P}<0.05$ ), while these parameters negatively correlated with PH, EC, TDS, T, ALK, $\mathrm{NO}_{3}, \mathrm{NO}_{2}$, and CL $(\mathrm{r}=-.729,-.234,-.237,-.086,-.052,-.290,-.290$, - .045, $\mathrm{P}<0.05)$, but there was no significant correlation between $\mathrm{NO}_{3}$ and $\mathrm{NO}_{2}$. At WWTP-B DO, $\mathrm{pH}, \mathrm{ALK}$, 


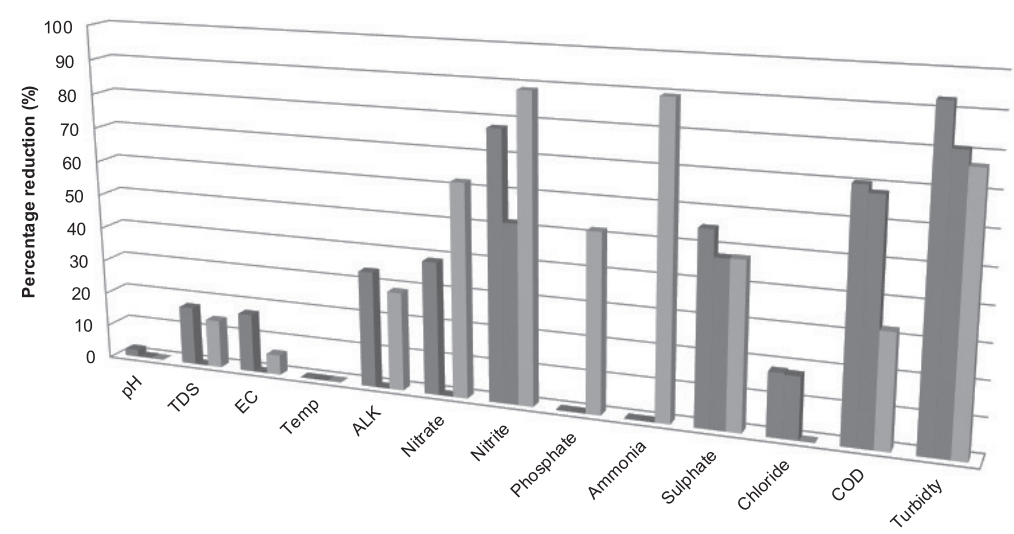

\begin{tabular}{|c|c|c|c|c|c|c|c|c|c|c|c|c|c|}
\hline & $\mathrm{pH}$ & TDS & EC & Temp & ALK & Nitrate & Nitrite & Phosphate & Ammonia & Sulphate & Chloride & COD & Turbidty \\
\hline - ALICE & 2 & 17,22 & 17,2 & 0 & 33,94 & 38,75 & 77,88 & 0 & 0 & 55,35 & 18,22 & 70,35 & 92,92 \\
\hline BEDFORD & 0,13 & 0 & 0 & 0 & 0 & 0 & 51,94 & 0 & 0 & 47,81 & 17,85 & 68,22 & 80,99 \\
\hline BERLIN & 0 & 14,15 & 5,85 & 0 & 28,8 & 62,11 & 88,71 & 51,89 & 89,42 & 47,95 & 0 & 32,63 & 76,87 \\
\hline
\end{tabular}

Fig. 1. Percentage reduction of physicochemical parameters at the three assessed wastewater plants.

$\mathrm{NH}_{4}, \mathrm{SO}_{4}, \mathrm{CL}, \mathrm{COD}, \mathrm{BOD}$, and TUR exhibited a positive significant correlation $(\mathrm{r}=.480, .844, .178, .035, .446$, $.100, .580, .422, .376, \mathrm{P}<0.05)$, while EC, TDS, $\mathrm{NO}_{3}, \mathrm{NO}_{2}$, $\mathrm{PO}_{4}$, and $\mathrm{RC}(\mathrm{r}=-.566,-.474,-.012,-.021,-.327$, $.665, \mathrm{P}<0.05)$ showed a negative significant $(\mathrm{P}<0.05)$ correlation, several positive and negative significant correlations were also obtained between the parameter at $(\mathrm{P}<0.01)$ in WWTP-A, WWTP-C, and WWTP-B, and the data obtained in this study also suggested significant $(\mathrm{P}<0.05)$ correlation between $\mathrm{DO}$ and other parameters that can lead to poor reduction efficiency of the municipal sewage facilities and also increase energy consumption.

The percentage reductions of the selected physicochemical parameters at the three treatment plants generally ranged $0.13-92.9 \%$ at the three sites (Fig. 1). The parameters with the highest percentages of reduction at Alice treatment plant were TUR and $\mathrm{NO}_{2}$, with more than $75 \%$ reduction, and $\mathrm{SO}_{4}$ with $55.4 \%$, while the other parameters were below $40 \%$. The Berlin treatment plant showed better efficiency in terms of pollutant reduction - more than the other two plants, having $\mathrm{NO}_{2}, \mathrm{NH}_{4}$, and TUR with reduction above $75 \%$. Also at this plant, the percentage reduction of $\mathrm{SO}_{4}, \mathrm{PO}_{4}$, and $\mathrm{NO}_{3}$ ranged between 48 and $62 \%$, while the reductions of remaining parameters were below 30\%. The Bedford plant with Oxidation pond technology was poor compared to the Alice and Berlin treatment plants, with only TUR above $75 \%$, while $\mathrm{NO}_{2}$ and $\mathrm{SO}_{4}$ had $52 \%$ and $47.8 \%$ reductions, respectively. Other parameters measured at this plant were below $20 \%$ in terms of reduction rates.

\section{Conclusions}

Challenges confronting the water and sanitation sector in South Africa appear to remain. The current study assessed the water quality of influent and effluent as well as the upstream and downstream areas of three treatment works. The results showed compliance of effluent quality for a few parameters (e.g., $\mathrm{pH}$ and phosphate) while others such as turbidity, electrical conductivity, nitrate, biochemical oxygen demand, and total dissolved solids among others did not comply with set limits for most of the sampling period. This study revealed a general deterioration in the physicochemical qualities of the discharged wastewater effluents as well as the receiving watershed, and suggests the inefficiency of the treatment works at producing effluents of acceptable quality together with its attendant environmental health challenges. The findings underscore the need for continuous pollution monitoring and intervention strategies to curb indiscriminate pollution of environments by the continuous release of inadequately treated effluents in South Africa and many other developing countries in order to forestall public health concerns associated with environmental pollution.

\section{Acknowledgements}

We are grateful to the South Africa Medical Research Council and the National Research Foundation for financial support.

\section{References}

1. FATTA-KASSINOS D., KALAVROUZIOTIS I., KOUKOULAKIS P. The risks associated with wastewater reuse and xenobiotics in the agroecological environment. Sci Total Environ. 408 (19), 3555, 2011.

2. TEKLEHAIMANOT G.Z., GENTHE B., KAMIKA I., MOMBA M.N.B. Prevalence of enteropathogenic bacteria in treated effluents and receiving water bodies and their potential health risks. Sci. Total Environ. 518, 441, 2015.

3. NAIDOO S., OLANIRAN A.O. Treated wastewater effluent as a source of microbial pollution of surface water resources. Int J Environ Res Public Healt. 11 (1), 249, 2013. 
4. RAJI M.I.O., IBRAHIM Y.K.E., TYTLER B.A., EHINMIDU J.O. Physicochemical Characteristics of Water Samples Collected from River Sokoto, Northwestern Nigeria. Atmospheric and Climate Sciences. 5 (03), 194 , 2015.

5. RANI D., MOREIRA M.M. Simulation-optimization modeling: a survey and potential application in reservoir systems operation. Water Resources Management. 24 (6), 1107,2010

6. PALLEN D. Environmental sourcebook for micro-finance institutions. Canadian International Development Agency, Asia Branch 1997.

7. ABDEL-RAOUF N., AL-HOMAIDAN A.A., IBRAHEEM I.B.M. Microalgae and wastewater treatment. Saudi J Biol Sci. 19 (3), 257, 2012.

8. MBALASSA M., BAGALWA M., NSHOMBO M., KATEYO M. Assessment of physicochemical parameters in relation with fish ecology in Ishasha River and Lake Edward, Albertine Rift Valley, East Africa. Int J Curr Microbiol Appl. 3, 230, 2014.

9. DIXIT R., MALAVIYA D., PANDIYAN K., SINGH U.B., SAHU A., SHUKLA R., SINGH B.P., RAI J.P., SHARMA P.K., LADE H., PAUL D. Bioremediation of heavy metals from soil and aquatic environment: an overview of principles and criteria of fundamental processes. Sustainability. 7 (2), 2189, 2015

10. AKPOR O.B., MUCHIE M. Remediation of heavy metals in drinking water and wastewater treatment systems: Processes and applications. Int. J. Phys. Sci. 5 (12), 1807, 2010.

11. SHESTIVSKA V., NEMEC A., DŘEVÍNEK P., SOVOVÁ K., DRYAHINA K., ŠPANĚL P. Quantification of methyl thiocyanate in the headspace of Pseudomonas aeruginosa cultures and in the breath of cystic fibrosis patients by selected ion flow tube mass spectrometry. Rapid Commun Mass Spectrom. 25 (17), 2459, 2011.

12. HENDERSON R.K., BAKER A., MURPHY K.R., HAMBLY A., STUETZ R.M., KHAN S.J. Fluorescence as a potential monitoring tool for recycled water systems: a review. Water Research. 43 (4), 863, 2009.

13. SAHNOUN R.D., BAKLOUTI S. Characterization of flat ceramic membrane supports prepared with kaolinphosphoric acid-starch. Applied Clay Science. 83, 399, 2013.

14. STEEL A.W., POSTGATE A.J., KHORSANDI S., NICHOLLS J., JIAO L., VLAVIANOS P., HABIB N., WESTABY D. Endoscopically applied radiofrequency ablation appears to be safe in the treatment of malignant biliary obstruction. World J. Gastrointest Endosc. 73 (1), 149, 2011.

15. MALASSA H., AL-QUTOB M., AL-KHATIB M., AL-RIMAWI, F. Determination of different trace heavy metals in ground water of South West Bank/Palestine by ICP/MS. Journal of Environmental Protection. 4 (08), 818, 2013.

16. MALASSA H., HADIDOUN M., AL-KHATIB M., ALRIMAWI F., AL-QUTOB M. Assessment of groundwater pollution with heavy metals in North West Bank/Palestine by ICP-MS. Journal of Environmental protection. 5 (1), 54, 2014.

17. APHA, Standard methods for the Examination of Water and Wastewater: Biochemical Oxygen demand. American Public Health Association, American Water Works Association, Water Environment Federation 1999.

18. OSODE A.N., OKOH A.I. Impact of discharged wastewater final effluent on the physicochemical qualities of a receiving watershed in a suburban community of the Eastern Cape Province. Clean - Soil, Air, Water. 37 (12), 938, 2009.

19. KUMAR V., CHOPRA A.K. Fertigation effect of distillery effluent on agronomical practices of Trigonella foenumgraecum L. (Fenugreek). Environ Monit Assess. 184 (3), 1207, 2012.

20. SINGH G., JOYCE E.M., BEDDOW J., MASON T.J. Evaluation of antibacterial activity of $\mathrm{ZnO}$ nanoparticles coated sonochemically onto textile fabrics. J. microbiol. biotechnol. Food sci. 2 (1), 106, 2012.

21. IGBINOSA E.O., OKOH A.I. Impact of discharge wastewater effluents on the physico-chemical qualities of a receiving watershed in a typical rural community, IJESD. 6 (2), 175, 2009.

22. DWAF; WRC. South African water quality management series. Procedures to Assess Effluent Discharge Impacts. Pretoria: Department of Water Affairs and Forestry and Water Research Commission. 2010.

23. MAMBA B.B., DLAMINI N.P., NYEMBE D.W., MULABA-BAFUBIANDI A.F. Metal adsorption capabilities of clinoptilolite and selected strains of bacteria from mine water. Physics and Chemistry of the Earth, Parts A/B/C. 34 (13), 830, 2009.

24. EWEMOJE O.E., IHUOMA S.O. Physicochemical changes in the quality of surface water due to sewage discharge in Ibadan, South-Western Nigeria. Energy and Environment Research. 4 (1), 55, 2014.

25. ODJADJARE E.E., OKOH A.I. Physicochemical quality of an urban municipal wastewater effluent and its impact on the receiving environment. Environ Monit Assess. 170 (1), 383, 2010.

26. MCCULLOCH J.S., ROBINSON M. History of forest hydrology. J Hydrol. 150 (2-4), 189, 1993.

27. ODJADJARE E.E.O., IGBINOSA E.O., OKOH A.I. Microbial and physicochemical quality of an urban reclaimed wastewater used for irrigation and aquaculture in South Africa. Afr. J. Microbiol. Res. 5 (15), 2179, 2011.

28. PAYMENT P., PLANTE R., CEJKA P. Removal of indicator bacteria, human enteric viruses, Giardia cysts, and Cryptosporidium oocysts at a large wastewater primary treatment facility. Canadian Journal of Microbiology. 47 (3), 188, 2001.

29. CHIGOR V.N., SIBANDA T., OKOH A.I. Variations in the physicochemical characteristics of the Buffalo River in the Eastern Cape Province of South Africa. Environ Monit Assess. 185 (10), 8733, 2013.

30. ANDERSON C.N., GRETHER G.F. Interspecific aggression and character displacement of competitor recognition in Hetaerina damselflies. Proc R Soc Lond B Biol Sci. 277 (1681), 549, 2010.

31. SALEQUZZAMAN M., ISLAM S.T., TASNUVA A., KASHEM M.A., MASUD M.M.A. Environmental impact of sugar industry a case study on Kushtia sugar mills in Bangladesh. J Innov Dev Strat. 2 (3), 31, 2008.

32. SALEM I.B., OUARDANI I., HASSINE M., AOUNI M. Bacteriological and physico-chemical assessment of wastewater in different region of Tunisia: impact on human health. BMC Res. Notes. 4 (1), 1, 2011.

33. DWAF; WRC. South African water quality management series. Procedures to Assess Effluent Discharge Impacts. Pretoria. Department of Water Affairs and Forestry and Water Research Commission 1999.

34. RAGHEB S.M. Phosphate removal from aqueous solution using slag and fly ash. HBRC Journal. 9 (3), 270, 2013.

35. MOOK W.T., CHAKRABARTI M.H., AROUA M.K., KHAN G.M.A., ALI B.S., ISLAM M.S., HASSAN M.A. 
Removal of total ammonia nitrogen (TAN), nitrate and total organic carbon (TOC) from aquaculture wastewater using electrochemical technology: A review. Desalination. 285, 1, 2012.

36. AKAN J.C., MOSES E.A., OGUGBUAJA V.O., ABAH I. Assessment of Tannery Industrial Effluents from Kano Metropolis, Kano State, Nigeria. Journal of Applied Sciences. 7 (19), $2788,2007$.

37. ROSHVANLO R.B., REZAEE A., HOSSINI H., SHIRI M. Ammonium Removal by Nitrification and Denitrification in an Integrated Fixed Film Activated Sludge Process. Health Scope. 3 (4), 2014.

38. EDOKPAYI J.N., ODIYO J.O., MSAGATI T.A., POPOOLA E.O. Removal efficiency of faecal indicator organisms, nutrients and heavy metals from a peri-urban wastewater treatment plant in Thohoyandou, Limpopo Province, South Africa. Int J Environ Res Public Health. 12 (7), 7300, 2015.

39. MORENO-CASILLAS H.A., COCKE D.L., GOMES J.A., MORKOVSKY P., PARGA J.R., PETERSON E. Electrocoagulation mechanism for COD removal. Separation and purification Technology. 56 (2), 204, 2007.
40. FATOKI O.S., GOGWANA P., OGUNFOWOKAN A.O. Pollution assessment in the Keiskamma River and in the impoundment downstream. Water SA. 29 (2), 183, 2003.

41. KIM T.H., LEE Y., HAN S.H., HWANG S.J. The effects of wavelength and wavelength mixing ratios on microalgae growth and nitrogen, phosphorus removal using Scenedesmus sp. for wastewater treatment. Bioresource Technology. 130, 75, 2013.

42. SAMANTARAY S., NAYAK J.K., MALLICK N. Wastewater utilization for poly- $\beta$-hydroxybutyrate production by the cyanobacterium Aulosira fertilissima in a recirculatory aquaculture system. Applied and Environmental Microbiology. 77 (24), 8735, 2011.

43. GOVERNMENT GAZATTE, Requirements for the purification of Wastewater or Effluent. Gazette No. 9225, Regulation No. 991, 18 May 1984.

44. NJOKU O.E., AGWA O.K., IBIENE A.A. An investigation of the microbiological and physicochemical profile of some fish pond water within the Niger Delta region of Nigeria. African Journal of Food Science. 9 (3), 155, 2015.

45. MAKAROVSKY I., MARKEL G., DUSHNITSKY T., EISENKRAFT A. Ammonia-when something smells wrong. IMAJ 10 (7), 537, 2008. 